\title{
Archéopages
}

Archéopages

Archéologie et société

\section{La vallée des Phoquiers aux îles Crozet. Un fondoir à graisse, témoin des premières occupations humaines}

Jean-François Le Mouël, Patrick Arnaud, Paul Courbon, Jacques Rebière, Nathalie Moreignaux et Édouard Jacquot

\section{CpenEdition}

Journals

Édition électronique

URL : https://journals.openedition.org/archeopages/501

DOI : 10.4000/archeopages.501

ISSN : 2269-9872

Éditeur

INRAP - Institut national de recherches archéologiques préventives

Édition imprimée

Date de publication : 1 août 2014

Pagination : 40-47

ISSN : $1622-8545$

\section{Référence électronique}

Jean-François Le Mouël, Patrick Arnaud, Paul Courbon, Jacques Rebière, Nathalie Moreignaux et Édouard Jacquot, «La vallée des Phoquiers aux îles Crozet. Un fondoir à graisse, témoin des premières occupations humaines ", Archéopages [En ligne], 38 | 07/2013, mis en ligne le 01 juillet 2015, consulté le 21 janvier 2022. URL : http://journals.openedition.org/archeopages/501 ; DOI : https://doi.org/10.4000/archeopages.501 


\title{
La vallée des Phoquiers aux îles Crozet Un fondoir à graisse, témoin des premières occupations humaines
}

\author{
Jean-François Le Mouël CNRS, Taaf» "Terres australesettantarctiquesfrançaises» \\ Patrick Arnaud CNRS, Taaf « Terres australese tantarctiquesfrançaises» \\ Paul Courbon géometrre-expert \\ Jacques Rebière Scop LC2R Draguignan, «Laboratoire de conservation, restauration, recherche» \\ Nathalie MoreignauX Taaf «Terres australes et antarctiques françaises» \\ Édouard Jacquot Ministere de la Culture, direction des Affaires culturelles - océan Indien \\ avec la collaboration de Serge Valcke et José Peral EURL Perazio Géomètre
}

\section{0}

\section{Îles Crozet, des îles subantarctiques}

Parmi les dernières terres de la planète occupées par l'espèce humaine, les îles subantarctiques restent pour l'homme un milieu extrême. Dans le sud de l'océan Indien, les Terres australes et antarctiques françaises (Taaf) administrent trois de ces territoires : Crozet, Kerguelen, Amsterdam \& Saint-Paul. Pour assurer ses missions de service public au bout du monde, cette collectivité d'outremer organise une liaison régulière grâce aux rotations d'un navire unique, le Marion Dufresne, et y maintient des bases habitées permanentes. Situé entre les $46^{\mathrm{e}}$ et $47^{\mathrm{e}}$ parallèles de l'hémisphère Sud, l'archipel Crozet [ill. 1] connaît un froid relatif, une pluviosité abondante et des vents violents. Vivre sous ce climat demande efforts et adaptations, mais ce sont surtout l'éloignement et le maintien de liens avec le reste du monde qui conditionnent l'activité humaine. Découvert en 1772, l'archipel est abordé à la période contemporaine. Depuis le milieu du $\mathrm{xx}^{\mathrm{e}}$ siècle, des expéditions régulières ont lieu. La base Alfred Faure y est créée en 1964 sur la plus grande des cinq îles. Aujourd'hui encore, c'est en fonction de l'accessibilité aux équipes et de la logistique matérielle que l'activité humaine se concentre sur l'île de La Possession. Hier comme aujourd'hui, ce sont les conditions d'isolement et les efforts déployés pour les surmonter qui font de ces îles un milieu extrême. Les activités pratiquées quelques décennies en arrière nous sont très familières, c'est pourquoi, afin d'interpréter le quotidien des hommes qui nous ont précédés sur ce territoire, les auteurs ont choisi de décrire en détail leur propre travail pour en retrouver les traces.

Les premiers à fréquenter ces côtes au XIX $\mathrm{X}^{\mathrm{e}}$ siècle sont principalement des Anglais et des Américains, qui récupèrent l'huile et la graisse animales, ressources précieuses pour les besoins énergétiques et mécaniques sous la première révolution industrielle. Dès 1803, le capitaine Edmund Fanning aborde La Possession à bord de la Catherine (Fanning, 1833). L'activité se fixe durablement au nord-est de lîle, sur un des rivages les plus accueillants, ouvert mais relativement abrité : une plage de sable noir de $900 \mathrm{~m}$ de long, située au débouché de la rivière Moby-Dick entre deux massifs montagneux. Appelée baie Américaine (ou baie US, abrégée en BUS), elle tire peut-être son nom des campagnes du navire baleinier American, mais rappelle surtout la nationalité qui fut dominante dans le secteur. Les phoquiers y chassaient les otaries et éléphants de mer par milliers.

D'autres événements ponctuent l'histoire des lieux. En décembre 1880, le site reçoit de la corvette anglaise HMS Comus un petit abri contenant vêtements et vivres pour 50 personnes pendant 50 jours. Ce secours destiné à d'éventuels naufragés s'avère hélas utile quand, le 4 décembre 1906, une goélette norvégienne est jetée à la côte, la Cathrine (presque homonyme du navire précité). Les rescapés y construisent une vaste cabane en bois d'épaves, matériau qui leur servait également pour le chauffage. Sur une façade, ils apposent la plaque de poupe de leur bateau. Cette habitation, baptisée Christmas House, leur permet de survivre dans des conditions relativement acceptables (Bull, 1908). Elle apparaît dans un numéro de la revue lllustrated London News du 26 septembre 1908 [ill. 2]. À bord d'une petite embarcation du nom d'Hopet, le capitaine et deux de ses hommes réussissent la tentative insensée de croiser la route des navires entre l'Afrique du Sud et l'Australie pour y chercher secours. Neuf jours après leur départ de Crozet, les trois hommes épuisés sont repérés par un navire hollandais, le De Ruyter, allant de Philadelphie au Japon! Débarqués à Sydney, ils lancent une alerte, et le navire néo-zélandais SS Turakina secourt les 11 derniers naufragés. En 1931, c'est finalement l'aviso 

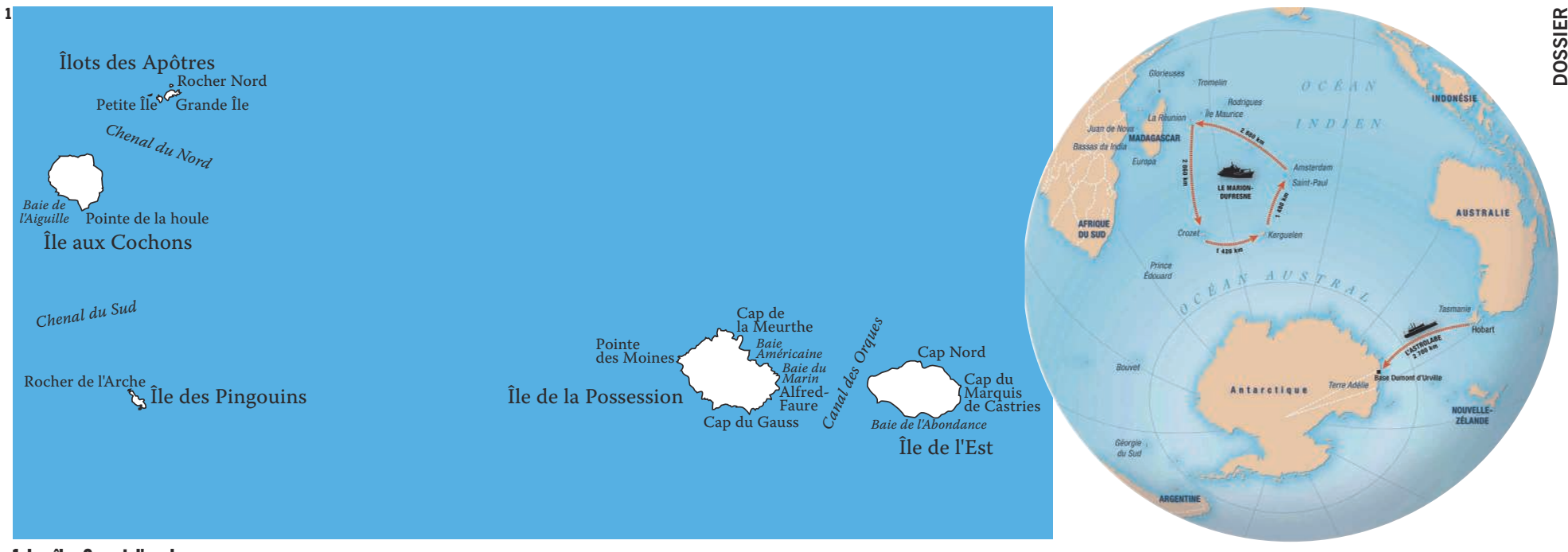

1. Les îles Crozet, l'un des cinq districts des Terres australes et antarctiques francaises, se situent entre les $46^{\circ}$ et $47^{\circ}$ parallèles de l'hémisphère Sud.
Antarès qui pose à BUS la borne qui marque la prise de possession officielle des îles Crozet par la France.

\section{Abris de BUS}

L'histoire des Taaf est récente et donc documentée par les textes et l'iconographie qui rapportent notamment l'activité de ces baleiniers et phoquiers en baie Américaine. En 1889, la revue L'Illustration publie ainsi une «vue» imaginaire d'un cimetière aperçu à l'époque, mais introuvable depuis (Anonyme, 1889). Sur le terrain également, les traces d'occupation sont trop évidentes pour passer inaperçues. L'intérêt historique des lieux est signalé dès 1969 par l'entomologiste anglais Lewis Davies, qui distingue à BUS deux sites différents (Davies, 1969).

Le premier est localisé au bord de la grande vallée, un minuscule vallon humide conservant un gros chaudron et des plateformes matérialisant des fonds de cabanes, bordés ou non de murets. Le chercheur y décrit même un pot de fer de $40 \mathrm{~cm}$ de diamètre contenant des patelles et des tronçons de côtes d'éléphants de mer, sans doute des restes alimentaires. Mais la collecte de « souvenirs » a hélas trop longtemps dépossédé les sites de leur mobilier. Parfois déposés à la base Alfred-Faure, certains artefacts sont susceptibles de provenir de la baie Américaine, comme un beau harpon. Emportés par des visiteurs, d'autres ont souvent disparu, tels un petit canon de salut et une baïonnette qui avait été observée sur le terrain par Patrick Arnaud.

Le second site se trouve à $300 \mathrm{~m}$ en suivant la plage au nord-est. Il s'organise autour d'un petit vallon abrité du vent, et précisément connu sous le nom de vallée des Phoquiers [ill. 3a]. À différents niveaux de la pente, se trouvent en effet les vestiges de trois constructions attribuables à leur installation. Ce sont des fonds de cabanes, en partie creusées dans le rocher et entourées de murets dont les assises marquent quatre structures. La vallée est recouverte par une végétation typique de l'archipel, composée de plantes basses, d'herbe, de mousse et de tourbe. Y coule un petit ruisseau qui débouche sur une plage étroite de sable, de galets et de blocs, submergée à marée haute et par forte mer.
C'est au nord de cette plage, et adossé à une petite falaise aujourd'hui léchée par les vagues, que l'on a découvert le vestige majeur du site, un aménagement qui était destiné à faire fondre la graisse des animaux marins. L'ensemble est constitué d'un très grand chaudron de fonte encore enchâssé dans une maçonnerie de pierre hourdée à la terre. Bien que la France n'ait pas elle-même joué un rôle majeur dans l'exploitation fort révolue des mammifères marins des mers froides, elle conserve beaucoup de chaudrons de baleiniers et de phoquiers, pour la plupart installés dans une structure. On appelle ces assemblages fondoirs à graisse. Certains, probablement les plus anciens, étaient construits en pierres, les autres, les plus nombreux, en briques importées. Si celui de la baie Américaine a pris la vedette dans la zone subantarctique, c'est en raison de sa structure unique, comportant un fourneau et une cheminée, et le fait qu'on a utilisé pour sa construction des pierres de basalte locales, ce qui explique un très bon état de conservation. Depuis son repérage en 1993, ce fondoir retient l'attention des Taaf, qui développent alors une politique de recherche archéologique et de conservation de leur patrimoine (Mourey, Le Mouël, 1996). Comme il faut le comprendre, les deux approches se confondent en fait dans les Taaf.

\section{Vingt ans de missions pour le patrimoine des Taaf}

L'archéologie de la période contemporaine est une discipline relativement nouvelle, qui démontre aujourd'hui son intérêt pour la sauvegarde des témoins matériels du passé le plus proche et familier. Dans les Terres australes et antarctiques françaises où cette période est seule représentée, cette discipline se développe sans précocité mais avec exemplarité (Le Mouël, 2002). Premier directeur du patrimoine des Taaf, Jean-François Le Mouël dirige dans les années 1990 et 2000 des travaux pionniers, inspirés de la méthodologie d'André Leroi-Gourhan pour l'ethnologie préhistorique et transposés grâce à un important travail sur l'Arctique, qui entraînent la France dans le développement de l'archéologique subantarctique. Les nombreux sites documentés 
THE ILLUSTRATED LONDON NEWS, SePT. 26, 1908.-430

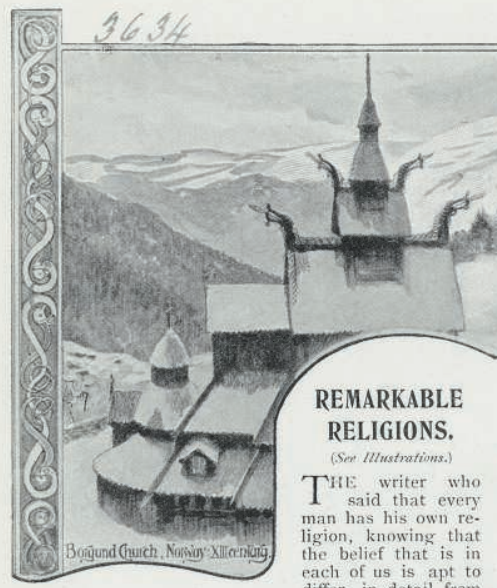

differ in detail from might almost have been taken literally, so many are the religions of the world. Nothing gives greater prominence
to the fact than the gathering together of models to the fact than the gathering together of models or
illustrations of worship in all climes - such a gathering
together, indeed, as that organised recently by the
London, Missionary Society. There, within the confines London Missionary Society. There, within the confines
of a London building, was an almost bewildering array of a London building, was an almost bewildering array
of the outward signs of the inward graces or superstitions of primitive and more enlightened man. Certain of these we illustrate elsewhere in this number, and
here we amplify somewhat the descriptions there given,

taking the drawings in order.
The worship of trees is general not only in China, but in Japan, and has the halo of antiguity about it. monies three sacred men played the chief part, al As a rule, the tree is an
old one - one that has with. stond the storms of agesand in it is supposed to live his dwelling-place: Venerable Father Fir - Tree, or what not. The tree shown
in the Illustration is credited in the Illustration is credited
with the possession of great
powers of healing.

The emu totem is of especial interest. "A to tem, says a definition, ". which a savage regards with superstitious respect, be-
lieving that there exists between him and every memtion." In Central Australia natives favour such totem as kangaroo, dingo, emu, tichiuma ceremonies take place once a year-in the breeding-season of the particular totem chosen by the
group. In the case of the group. In the case of the
emu, blood is taken from the arms of the men, allowed to dry on the ground, and made to form the basi of a rough drawing of the
anatomy of the emu. Further ceremonies take place round this, and on the following morning other rites
are performed by two natives. are performed by two natives
so painted and adorned that its long neck, who imitate in primitive fashion the movements of the bird. Tahiti, was looked upon as of them painted red, and the centre one wearing a
The god Ta'aroa, of The creator of all things. Its back great mask of tortoiseshell, with a beard made of
the God of Heaven, creator could be removed, and in the hollow thus disclosed were a number of figures, designed to illustrate the creative powers of the idol.
The Becluana reed-dance yields proof that among the Bechuana people are still to be found signs of the totem. When a native asks another's tribe, he says,
"What do you dance?" and the dance is a most important part of his religion. in recognition of the power that enables them to in recognition of the power that enables them the
kill some twenty thousand Indians each year. The annual festival known as Nag Panchami is given up to the cobra in particular, and it is then espe-
cially that the snake, in the form of clay images, is worslupped. of Peking, and is of white marble. At it the Emperor as High Priest of the Chinese, offers up worship and sacnfice to Heaven on equally important, are those wayside shrines at which animals are worshipped - the fox, the weasel, the hedgehog, the snake, and the rat (otherwise, the nd no woman or girl may enter a house containing Roche New Hebrdes. The was prevalent. The chief hero was known to the un-

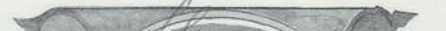
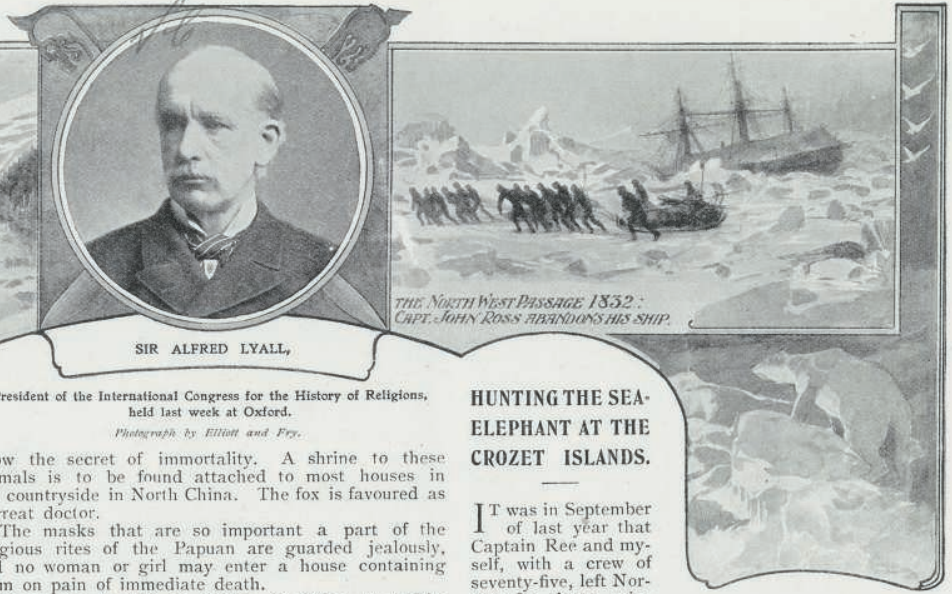
Reverence is paid to stones-or rather, to spirits
Rente thirty miles below the earth's surface, and becomes at once a power for good or evil in the lives of the living.
In this stage he is called "namata." In Malekula every llage has its clearing for namata ceremonies, and there re the sacred stone and a semicircle of tree-stumps On Murray Island, in the Torres Straits, hero-worship be lown only to the initiated and revealed on

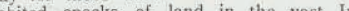
that are known as the Crozet Islands ; reached, them, all well, towards the end of the following November. If the hunting of the sea-elephant could in
any way be compared with the pursuit of his namesake ashore, we should be permitted to boast of having broken all records as elephant-hunters, for during the two months, December and January, from seven to their lives to our party of " blubber-hunters." But, alas! from a sportsman's view, no game
the lazy, defenceless sea-elephant

Captain Weddell, of Antarctic fame, gave the follow-
description of the sea-elephant, and although his experiences were gathered at the South Shet 1820-24, the description applies in most particulars to the animals at the Crozetsproboscis extending a warty six inches from the snout. somewhat similar to that of the common elephant, and
hence the name of this kind of the seal species.
kind larger than the females, and may reach twenty-four feet in length and fourteen feet are usually In shape they have the appearance of the common
seal. The males go on seal. The males go on
shore towards the end of shortly after. When they first land, the sea-elephants are exceedingly fat, and on
an average the blubber of seven animals will then go seven animals will then go
to the ton. During their life ashore. for upwards of
several months, they subsist by absorbing their own fat, so that after some weeks
of this kind of existence they are getting meagre,
and their commercial value considerably decreasing." It may be said further usually found in flocks of from thirty to a hundred, take very little notice of the
hunter, and allow him to hunter, and allow him to
approach as near to them as
them, therefore, is more like Ancestor-worship is found in the eastern half of the
Ancin lower-jaw bones. continent of Africa. The scene in which Lobengula
. Thears as chief actor shows the King, who wal both King and priest dedicating to warticul ancestors some two hundred black oxen destined for he sacrifice.

The Kitchen God of China is, perhaps, not rightly the "Recording Angel " of the Chinese house, and
the and is his duty to note the actions of each member of the family and report them to the gods at the end of ever month. Once a year, too, he goes to Heaven in person, and makes his annual report. So, once him in procession, and finally burn him, while rackers are fired.

The ancestor-worship of China is too well known to call for much description, but it may be said that the relegated to the background as new ones come to take their place. Ancestors are seldom worshipped individually after the third generation, and never afte furned to the isian he wishes. The killing of
butchery than hunting, and is repulsive in the extreme. But the fat-blubber that is theirs yields a fine oil, oil that
may be turned into gold, and where gold is concerned it is remarkable how feelings of disgust can be subdued. We anchored in American Bay on Nov, 26 and the weather being fine, and the swell on the shore moderate, we secured a couple of boat-loads of our quarry during the afternoon. More fine days followed. tons of blubber, together with abins of young animats. During the month of December our work contimued at high pressure; towards the middle of January we had some six hundred tons on board, and on the Ist of Febstary the iron taks in which the oil and blubber were hundred tons of oil. In addition, we h skins of young animals, which are saleable at farly good prices. Had the season not been somewhat adof the mon we rached he Islands, and had the majority of the young sea-elephants not taken to the water, our youngsters alone are fit for the market. The heavy, porous hides of the old animals scarcely repay the processes.
H. J. BuLL. 
permettent ainsi de restituer l'histoire de ces terres australes, des premières occupations aux tentatives d'exploitation économique, des vestiges de naufrages aux sites d'observation et d'expérimentation scientifiques. Des éléments importants sont depuis protégés, conservés et restaurés afin de transmettre ce patrimoine (Le Mouël, 2004 ; Mouchel-Blaisot et al., 2008).

Jean-François Le Mouël entreprend ainsi un travail régulier sur la vallée des Phoquiers. Dès 1993, une première mission se rend sur le terrain accompagnée d'Éric Hervé, jeune topographe, et de Sophie Serra, étudiante en archéologie. En 1998, une mission est tout entière consacrée au site, et expérimente les conditions pluvieuses de travail en contexte crozétien. La topographie continue, toujours avec Éric Hervé, et des sondages de reconnaissance sont menés sur le site par William Mourey. Des constats réguliers sont établis sur l'état du fondoir (Walton, 2003), qui apparaît véritablement en danger : menacé non seulement par l'érosion marine et l'action de sape de la mer, le site l'est également par le ruissellement de la pluie sur la falaise contre laquelle il s'appuie. Un début de relevé est entrepris par Thomas Arnoux. Régulièrement, des dispositions provisoires sont prises pour la consolidation du pied de falaise, avec la dépose par hélicoptère de grands sacs (big bags) de sable destinés à amortir l'action des vagues. Au cours de ses missions, l'architecte Éric Zeimert effectue des observations et préconise une sauvegarde in situ (Zeimert, 2003). Des points de repère sont relevés pour surveiller les mouvements des vestiges (Zeimert, 2005). Mais ces mesures restent insuffisantes : les sacs vides sont dispersés sur la plage, tandis que la mer s'approche irrémédiablement du fondoir, risquant de l'emporter au cours d'une prochaine grosse tempête. Les Taaf réfléchissent à un dispositif de protection plus lourd, mais ce dernier aurait nécessité une meilleure connaissance de l'hydrologie de la baie, et risquait surtout de dénaturer le paysage. Plusieurs fois discuté en commission, le choix se portera finalement sur le déplacement du fondoir, en procédant à un démontage méthodique de l'ensemble, en prévision de son remontage à l'identique sur un autre site.

\section{Opération «Obélix»}

Si le grand public comprend immédiatement la référence au personnage, l'opération « Obélix », hommage à la célèbre bande dessinée, est une mission archéologique unique et inédite, aujourd'hui en voie d'achèvement. Il s'agit du sauvetage du fondoir à graisse et de son magnifique chaudron de phoquiers, entrepris en 2006 par l'équipe de Jean-François Le Mouël, à laquelle participaient le géomètreexpert Paul Courbon, l'archéologue Alexandra Barbot et Nicolas Dantec pour la logistique (Le Mouël, 2006). L'objectif de l'opération est de déconstruire la structure pour la reconstruire dans un endroit plus abrité, et pour cela d'en réaliser un schéma précis. La mission se déroule du 10 novembre au 11 décembre 2006, entre deux rotations du Marion Dufresne à Crozet. Elle est acheminée par le navire en baie Américaine, où les transbordements de personnel, de matériel et de ravitaillement sont assurés par rotations d'hélicoptère. Elle s'installe dans deux bâtiments, les fameux abris BUS, un pour le stockage des provisions nécessaires à l'alimentation, au chauffage et à l'électricité, l'autre pour l'hébergement qui, sur 3,5 par $3 \mathrm{~m}$, contient quatre lits superposés, une petite table et un coin cuisine. Comme salle de bains, la rivière qui coule non loin, avec une eau à quelques degrés et la compagnie des manchots, proches voisins. Aujourd'hui devenues réserve naturelle, les terres australes sont le domaine des animaux, qui vivent à l'état sauvage et ne craignent pas l'homme, qui ne les chasse plus depuis longtemps.

La topographie a été réalisée à l'aide d'un théodolite électronique et d'un ordinateur portable équipé d'un logiciel approprié. Après avoir relevé l'ensemble de la vallée des Phoquiers et des structures repérées, il s'agit de réaliser une topographie précise du fondoir à graisse (Courbon, 2012). L'action de sape des vagues a placé la structure sur un surplomb de plus en plus instable. Afin de limiter les risques pour le travail des archéologues sur l'étroite plateforme, il faut avant tout évacuer l'eau qui emplit le récipient. Le chaudron lui-même est en fonte; il a un diamètre extérieur de 1,20 $\mathrm{m}$ à son endroit le plus bombé et une profondeur de $0,77 \mathrm{~m}$; sa contenance à ras bord est évaluée à 600 l et son poids à environ $600 \mathrm{~kg}$; son orifice est de forme circulaire cassée par deux méplats diamétralement opposés.

Le monument est ensuite nettoyé, ce qui permet de délimiter les vestiges de leur environnement, et de mettre au jour l'appareillage. II s'agit d'une maçonnerie rustique constituée d'une part du fourneau, qui supporte le chaudron et permet d'aménager sous ce dernier un foyer dont on distingue l'ouverture en avant de la structure, et d'autre part d'une cheminée de $4 \mathrm{~m}$ de rejet, bâtie en arrière sur l'escarpement pour évacuer la fumée. Le chaudron apparaît suspendu, puisqu'un espace vide existe au niveau de l'alandier. Dans le foyer, une couche solidifiée de cendres et de graisse fondue atteste l'utilisation de ce combustible pour la chauffe. De forme très irrégulière, la structure est constituée de galets de basalte arrondis par la mer, montés de manière grossière, certains dépassant beaucoup par rapport aux autres, et assemblés avec un mélange de terre et de tourbe induré par le feu. L'action de l'humidité depuis l'abandon de la structure et sa végétalisation ont favorisé le glissement de galets.

Tous les éléments encore en place sont alors numérotés, pour pouvoir reporter leur position sur un schéma. La numérotation des pierres s'était limitée en 2002 à la cheminée, il fallait donc en 2006 poursuivre avec le fourneau. Ce travail commence sur le parement et se poursuit à l'intérieur de la maçonnerie, accompagné de nombreuses photographies et marques de repères, à raison de trois ou quatre points par pierre. Il est complété de croquis 

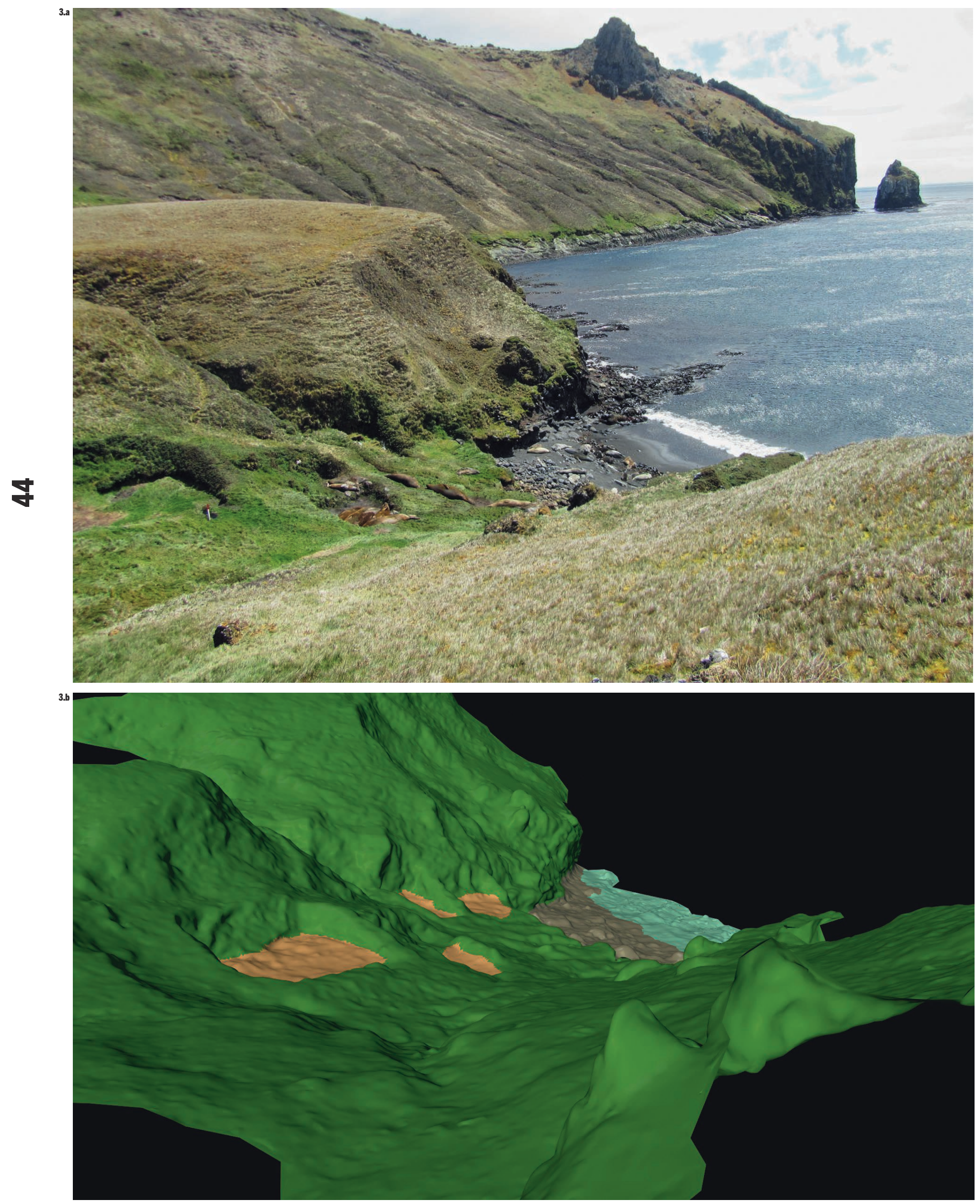
nécessaires au report de la topographie et à l'exécution de plusieurs plans et profils de coupe [ill. 4a et b].

Le démontage proprement dit constitue une étape très lourde [ill. 4c]. Il commence par la cheminée, où d'un tuyau métallique ne reste qu'une dentelle oxydée, et continue au niveau du fourneau. L'opération confirme que le chaudron était soutenu par des tiges de fer passant dans ses oreilles et reposant ellesmêmes sur deux massifs construits en encorbellement. Ils sont donc démontés en dernier, en faisant basculer le chaudron d'un côté et de l'autre par un système de levier. Des bastings sont installés pour maintenir le chaudron en place en attendant son enlèvement. Les pierres, pesant chacune de 15 à $120 \mathrm{~kg}$, sont acheminées jusqu'aux abris BUS, sur $300 \mathrm{~m}$ de distance. L'engin à chenilles prévu pour le transport tombe en panne dès le début de l'opération et ne peut être réparé, faute de pièce de rechange sur place. C'est à ce moment qu'apparaît la limite indépassable dans les Taaf, liée aux difficultés d'approvisionnement en dehors des passages du Marion Dufresne : seul le rapatriement des personnes est envisagé par d'autres navires en cas de nécessité médicale. Avec le concours de trois militaires venus de la base Alfred-Faure, à deux heures de marche, les cinq tonnes de pierres sont donc transportées par la seule force humaine sur la plage où se vautrent de nombreux éléphants de mer. Si les petites pierres peuvent être portées, les plus lourdes doivent être tirées sur le sable et les galets à l'aide d'une civière, par deux ou trois personnes. Les pierres sont stockées à BUS dans une caisse et y restent plusieurs année. En 2012, leur position est menacée par un déplacement du lit de la rivière, elles sont donc reconditionnées par des volontaires et évacuées par hélicoptère début 2013 vers Alfred-Faure. Dans les Taaf, l'hélicoptère est un engin irremplaçable pour le transport de matériel et de personnel, que manœuvrent les pilotes émérites de la compagnie réunionnaise Hélilagon. Dès 2006, le chaudron était quant à lui enlevé directement sur site. Grâce aux poutres qui le soutiennent par-dessous, il est placé dans un filet, lui-même arrimé à deux barres à mine fichées dans la paroi au-dessus. Ce système permet de répartir les contraintes sur toute la surface de l'objet, en état de corrosion avancée. Le chaudron peut ainsi être élingué et hélitreuillé (sling) pour être posé dans une caisse spécialement fabriquée par le menuisier de la base, en vue de son transport. On l'embarque enfin sur le Marion Dufresne vers La Réunion, destination : la métropole.

\section{Quatre ans de bain pour le chaudron}

La situation extrême des sites rend difficiles les interventions sur place et la recherche de traitement in situ. William Mourey a expérimenté l'emploi d'anodes artificielles sur plusieurs chaudrons de Crozet (Arnaud, Baratin, Le Mouël, 2002). En profitant de la forte humidité ambiante et en reliant le métal de l'objet

à des masselottes faites d'un alliage d'aluminium et de manganèse, il s'agissait de limiter la corrosion d'objets lourds et massifs. Plusieurs années après sa mise en place, les résultats n'ont pas été probants: problèmes d'arrachement, d'inégale exposition à l'humidité (certaines parties baignaient dans l'eau, d'autres étaient sèches), mauvaise maîtrise des flux électriques...

Le chaudron prélevé à la vallée des Phoquiers et rapatrié en métropole a pu bénéficier d'un traitement plus approprié, au Laboratoire de conservation, restauration, recherche $\left(\mathrm{LC}_{2} \mathrm{R}\right) \mathrm{de}$ Draguignan, sous la direction de Jacques Rebière, avec l'aide de Françoise Mielcarek. Un examen de la surface de l'objet mettant en évidence des signes de corrosion active due aux chlorures de fer, une stabilisation chimique a été entreprise. Dans une cuve mobile aménagée pour recevoir plusieurs bâches étanches, une solution d'eau osmosée a été mélangée à $2 \% \mathrm{~m} / \mathrm{m}$ d'hydroxyde de sodium puis agitée et chauffée 24h/24h. Quatre ans de bain ont été nécessaires. Le chaudron en a été sorti en septembre 2013. L'objet a été ensuite rincé dans l'eau osmosée et sa surface dégagée mécaniquement par sablage. Il a enfin subi une passivation par acide tannique à $10 \% \mathrm{~m} / \mathrm{m}$ dans l'eau distillée, suivie d'une protection mécanique par application de paraloïd B72 à $10 \% \mathrm{~m} / \mathrm{m}$ et d'une très fine couche de cire microcristalline. En cette année 2014, le chaudron est restauré, et prêt à retrouver les pierres du fourneau pour remonter le fondoir complet. Considérant le budget et le temps investis, les réflexions se poursuivent cependant quant au choix définitif du lieu d'exposition permanente.

\section{Visite virtuelle de la vallée des Phoquiers}

Sensibilisé par cet héritage, Jacques Rebière relance en décembre 2010, avec Nathalie Moreigneaux, une mission pour le patrimoine des Taaf (Rebière, 2011), accompagnée par Patrick Arnaud et Alain Charron, et lintervention du cabinet de géomètre-expert Perazio, représenté sur le terrain par Serge Valcke et José Peral (Perazio, 2011). Faisant appel au progrès des nouvelles technologies, le projet consiste à numériser par lasergrammétrie (ou laser $3 \mathrm{D}$ ) en trois dimensions et très haute définition plusieurs sites archéologiques des terres australes. Il s'agit d'enregistrer, à des fins conservatoires, une sauvegarde de vestiges dont la survie matérielle est menacée à plus ou moins long terme. Ce travail obéit aussi à la volonté de restituer ce patrimoine du bout du monde à tous les publics qui n'ont pas accès à ce territoire. La mission est préparée et équipée pour travailler dans des conditions climatiques difficiles et des terrains isolés des bases. Parmi tous les sites des terres australes choisis en 2010 pour la richesse et la diversité de leur patrimoine, la vallée des Phoquiers à baie Américaine est le premier numérisé. Seize stations sont réalisées, couvrant à chaque fois un champ de $40 \mathrm{~cm}$ à $40 \mathrm{~m}$ autour du scanner. Des dizaines de millions de points topographiques sont relevés en quelques minutes avec une précision de quelques millimètres. La numérisation est complétée par 78 prises de vue photographiques. Les données brutes sont ensuite 
FONDOIR À GRAISSE DES PHOQUIERS

Île de la Possession

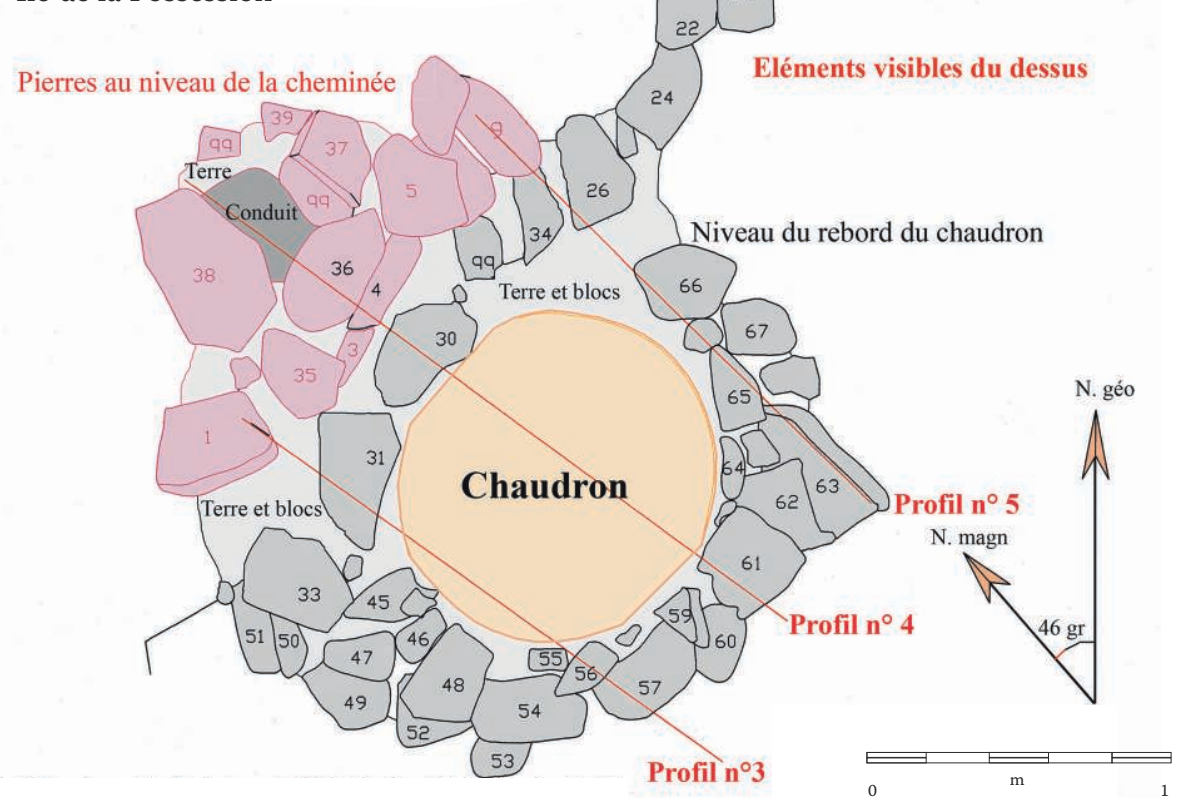

4.a et b. Le fondoir à

graisse, découvert au nord de la plage de la vallée des Phoquiers, construit en pierres de basalte locales, présente une structure unique constituée d'un fourneau et d'une cheminée. Des bigs bags (grands sacs de sable) protègent des vagues le pied de falaise. 4.c. Le démontage du fondoir, en 2006 (le linteau de l'alandier était brisé de longue date),

s'est fait en plusieurs

étapes, à commencer par la cheminée. Des bastings ont été installés pour

maintenir le chaudron en place jusqu'à ce qu'il soit enlevé : les pierres qui

l'entourent pèsent chacune de 15 à $120 \mathrm{~kg}$.

b FONDOIR À GRAISSE

Mise en place du chaudron et de la cheminée
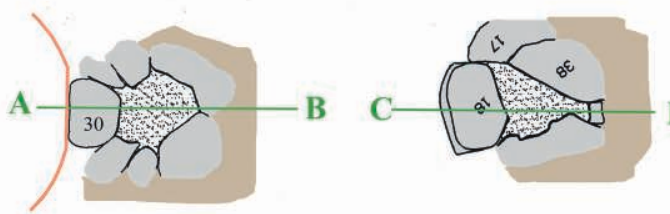

D
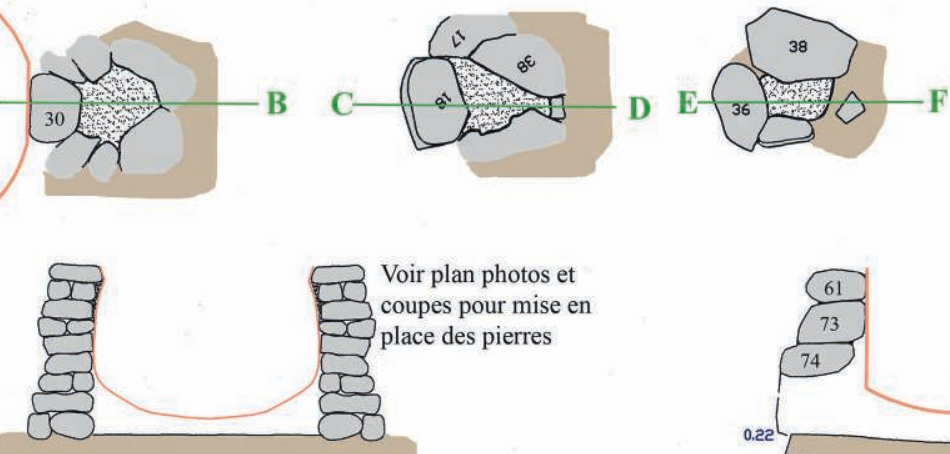

Fond du chaudron $0.31 \mathrm{~m}$ au dessus de la dalle

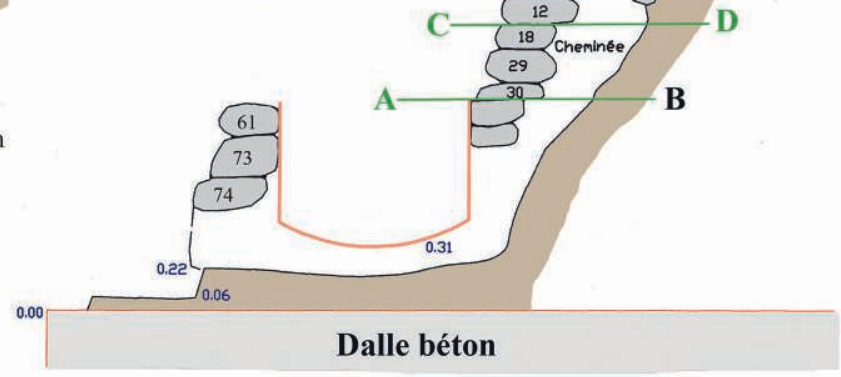

Certaines pierres sont non numérotées car non apparentes au moment du lever
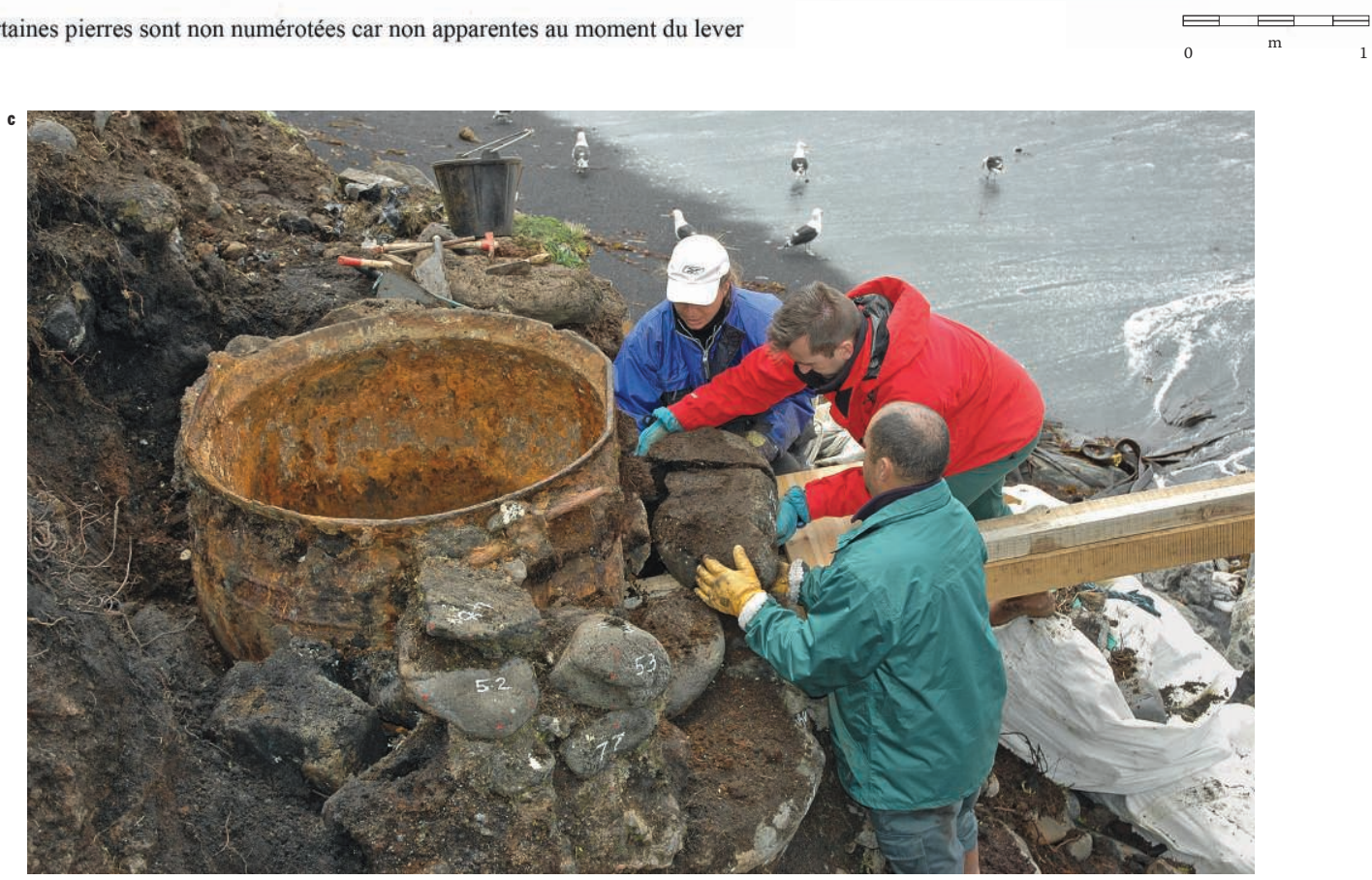
filtrées et sélectionnées pour ne conserver que le nuage de points utile au site. Les acquisitions des différentes stations sont référencées et assemblées. Il s'agit de créer un réseau d'un grand nombre de points de précision, qui, associés aux photographies, permettront de mieux comprendre les structures et de modéliser le site en images de synthèse [ill. 3b]. Également long et coûteux, ce traitement informatique se poursuit pendant plusieurs années. À la suite de l'ancienne station baleinière de Port-Jeanne-d'Arc aux Kerguelen, la vallée des Phoquiers de Crozet sera bientôt restituée et accessible à une visite sur Internet.

\section{$\mathrm{OP}_{3} 2012$ : une fortune de mer à Crozet}

Une nouvelle mission patrimoine est organisée en 2012, dans le cadre d'un partenariat avec le ministère de la Culture et de la Communication, en convention avec la direction des Affaires culturelles - océan Indien (Dac-OI) à La Réunion. Nathalie Moreigneaux et Jacques Rebière, accompagnés d'Édouard Jacquot, conservateur régional de l'archéologie, partent en rotation pour réaliser une expertise du patrimoine archéologique, notamment à Kerguelen où la mission doit séjourner jusqu'au retour du bateau. Une fortune de mer en décide autrement, quand, le 14 novembre 2012, le Marion Dufresne talonne un haut-fond au large de lîle de La Possession. L'opération australe « $\mathrm{OP}_{3} 2012$ » s'interrompt à Crozet et n'ira pas à Kerguelen. Les équipes sont hébergées sur la base Alfred-Faure en attendant le navire qui viendra les secourir. Ce sera le Léon Thévenin, qui les acheminera finalement jusqu'au Cap, en Afrique du Sud.

Au cours de cette semaine improbable et grâce à la logistique des Taaf, impeccable malgré les circonstances, une autre mission patrimoine est improvisée, mais organisée avec méthode sur l'île de La Possession. L'équipe saisit ainsi la possibilité de retourner une journée à baie Américaine pour travailler dans la vallée des Phoquiers. Sur le site, on constate que l'érosion marine a beaucoup progressé. Exposant irrémédiablement l'ancien emplacement du fondoir, elle a aussi agi comme révélateur, en attaquant la couche de terre et de végétation qui tapisse le fond de la vallée. Dans ces coupes naturelles, apparaissent en effet des structures en creux et des objets, probablement des déchets. On procède alors au nettoyage et au relevé de ces coupes, collectant dans ces rejets d'intéressants objets du quotidien des phoquiers : pièces métalliques (clou en alliage cuivreux, chaîne en fer, morceau de plomb), fragments de récipients en verre, bouts de bois... Des échantillons xylologiques, prélevés en 2010 sur le site et analysés par Frédéric Guibal à l'Institut méditerranéen d'écologie et de paléoécologie, permettent d'identifier du pin sylvestre, de l'épicéa et du pruche, une espèce originaire du Canada, dont la présence n'étonnera pas à baie Américaine. Ces résultats révèlent un potentiel encore important pour la connaissance de l'histoire subantarctique, et confirment donc l'intérêt d'une nouvelle fouille archéologique de la vallée des Phoquiers.

\section{Transmission et pérennisation d'un patrimoine}

Vingt ans de travail pour le patrimoine des Taaf ont abouti à y considérer et protéger ces traces d'un passé proche et familier comme un véritable patrimoine culturel. À chaque mission nous passons le relais, avec aujourd'hui le recrutement d'une volontaire du service civique auprès du service de l'archéologie, qui travaille à la structuration des projets dans la zone sud-ouest de l'océan Indien. Nous achevons ainsi l'inventaire des sites, objets et documents pour mieux les conserver, les étudier et les valoriser. Nous poursuivons aussi l'exploration des îles subantarctiques à la recherche des traces archéologiques de leur histoire humaine. Nous continuerons à sensibiliser nos contemporains, pour développer les mêmes réflexes que ceux aujourd'hui acquis pour le respect de l'environnement naturel, chez les personnes qui se succèdent sur ce territoire sans l'habiter plus d'une année. Notre dernière mission à Crozet traduit précisément ce qu'est l'archéologie australe : l'exploration des traces laissées sur ces terres du bout du monde, par celles et ceux qui nous y ont précédés il n'y a pas si longtemps, et qui, toutes proportions gardées, ont été contraints aussi de s'y adapter et de s'y entraider. Depuis son berceau, n'est-ce pas ce qui a guidé l'humanité dans les milieux les plus extrêmes de la planète? Pour finir, les auteurs remercient donc toutes les personnes qui, à tous les niveaux, ont travaillé, travaillent et travailleront pour le patrimoine des Taaf!
Références bibliographiques

ANONYME, 1889: « Les naufragés du Tamaris », L'Illustration, 92, p. 502-503.

Arnaud P., BARATIN J.-F., Le Moü̈L J.-F., 2002: Commission des sites et du patrimoine culturel. Rapport de la première mission dans les districts de Crozet, de Kerguelen, et d'Amsterdam du 21 août au 19 septembre 2002, Taaf, $28 \mathrm{p}$.

Bull H. J., 1908: « Hunting the sea elephants at the Crozet islands », The lllustrated London News, p. 430.

Courbon P., 2012:Lechaudron de Crozet, Rapport, Taaf, $7 \mathrm{p}$.

DAvies L., 1969: « Remains of sealer's activities at baie Américaine, île de La Possession, îles Crozet », Polar Rec., 14 (93), p. 848.

FANNING E., 1833: Voyages round the world..., New York, Collins \& Hannay, $499 \mathrm{p}$.

LE MOUËL J.-F., 2002 : « Mémoire d'outre-mer, mémoire d'outre-monde. L'émergence tardive d'une conscience patrimoniale dans le Territoire des terres australes et antarctiques françaises [Taaf] », in PÉRON F. (DIR.), $L e$ patrimoine maritime, Rennes, Presses universitaires de Rennes 2 (coll. Art et Société), p. 148-158.

LE MOUËL J.-F., 2004: « Heritage in the french subantarctic territory: between urgency and emergency», Cultural heritage in the arctic and antarctic region. Monuments and Sites, VIII, p. 6o-64.

LE Moü̈L J.-F., 2006:Rapport Mission Patrimoine, Taaf, 13 p. Mouchel-Blaisot R., Rebière J., Moreigneaux N., Peral J., VAlCKe S., 2008: « Pour une valorisation du patrimoine industriel des Taaf », in Pergola P., REBIÈRE J. (DIR.), Actes de Mariana. Conserver, étudier, protéger, valoriser le patrimoine en milieu isolé, Bastia-Lucciana, 9-12 oct. 2008, Bastia-Lucciana.
Mourey W., Le MouëL J.-F., 1996 : Proposition pour la conservation du patrimoine des îles Crozet, Kerguelen, Saint-Paul E Amsterdam, campagne 1995-1996, Rapport à M. le ministre des Dom-Tom et à M. l'administrateur supérieur, Taaf, $50 \mathrm{p}$.

Perazio, 2011: Mission OP4 2010. Note de synthèse, Moirans, Cabinet Perazio, $19 \mathrm{p}$.

REBIÈRE J., 2011 : Mission patrimoine 2010. Rapport à M. le préfet des Terres australes et antarctiques françaises. Éléments d'une stratégie de valorisation et d'étude du patrimoine des Taaf, Draguignan, $\mathrm{LC}_{2} \mathrm{R}, 37 \mathrm{p}$.

ZeIMERT E., 2003 : Rotation 2003, compte rendu, Taaf, 8 p. ZeImert E., 2005: Taaf, patrimoine. Rapport de visite, Taaf,, 64 p.

WALTON D., 2003 : « Report to Jean-François Le Mouël on "Le Patrimoine" », British Antarctic Survey, 9 p. 